\title{
Teachers' Professional Well-Being: State and Factors
}

\author{
Alexander Fedorov ${ }^{1, *}$, Elena Ilaltdinova ${ }^{2}$, Svetlana Frolova ${ }^{3}$ \\ ${ }^{1}$ Rector, Immanuel Kant Baltic Federal University, Kaliningrad, Russia \\ ${ }^{2}$ Rector, Minin Nizhny Novgorod Pedagogical University, Nizhny Novgorod, Russia \\ ${ }^{3}$ Vice-Director, Institute of Strategic Development, Minin Nizhny Novgorod Pedagogical University, Nizhny Novgorod, Russia
}

Received December 18, 2019; Revised April 9, 2020; Accepted April 27, 2020

Copyright $\mathrm{C} 2020$ by authors, all rights reserved. Authors agree that this article remains permanently open access under the terms of the Creative Commons Attribution License 4.0 International License

\begin{abstract}
The study is aimed, firstly, at the formation of a holistic, relevant, reliable picture of modern Russian teachers in the context of such characteristics as their professional well-being, and secondly, at the identification of factors and conditions of the educational space that contribute to or negatively affect the growth of professional well-being of a secondary school teacher. The article considers the problem of teachers' professional well-being, which is one of the determining factors in a teacher's professional growth, success, motivation, and professional activities. The problem of the low level of social prestige of the profession in society remains relevant, considering the constant increase in the importance of tasks, complexity of functions, and growth of expectations and requirements from the society, state and public. The authors analyze the phenomenon of professional well-being in Western and Russian psychology and sociology, defining by its essential determinants the state of professional activity processes and an individual's attitude toward the results in the multicomponent structure of social and psychological well-being. The article is empirical. In order to measure the professional well-being of teachers, the methods of factorization, psychometric measurements, mathematical and statistical data processing were applied. The measurement was based on a system of descriptors: professional growth, professional self-acceptance, positive relationships with colleagues and autonomy in professional activities. The study involved 192 teachers. The level of professional well-being of school teachers has been determined based on the descriptors; some factors and conditions that positively affect their professional well-being have been identified.
\end{abstract}

Keywords Teachers' Professional Well-Being, Professional Growth, Professional Self-Acceptance, Professional Relationships, Autonomy in Professional Activities

\section{Introduction}

\subsection{Problem Statement}

Professional well-being is one of the indicators that stand out in the multicomponent structure of social well-being [1].

The professional well-being of a teacher [2] is not determined solely by the availability of employment opportunities in the educational field. In this analysis context, teachers' professional well-being should be considered through the existing teachers' opportunities to realize themselves in the profession $[3,4]$.

Professionally successful teachers see work as favorite activities that allow them to realize their strengths and achieve their goals. For the teaching profession, the category of enthusiasm is central [5]. In the framework of the Russian tradition, dealing with the domestic ideal of a teacher, this thesis is justified both by the historical and pedagogical analysis of the domestic pedagogical tradition [6] devoted to the consideration of the requirements to the profession and by contemporary studies [7] demonstrating expectations of a director's corpus from a teacher. Among teachers' professional and personal qualities that were most frequently mentioned by the respondents are fascination, interest, and enthusiasm. Moreover, a number of other qualities, for example, a desire for constant self-development and self-improvement, are fundamentally related to their professional activities as a favorite occupation and to the relationships with all education subjects.

\subsection{Relevance}

Teachers' professional well-being is determined both by the measures of state policy in the field of education and social sphere, which are external to a person, and the subjective assessment of teachers themselves, a professional teaching community of different levels of 
satisfaction with their professional, social, economic and cultural needs [8].

Among the indicators of the state policy effectiveness in the sphere of education and staff assistance in education, it seems appropriate to take into account the conditions that contribute to implementing a teacher's needs, defining the awareness and feeling of professional and social well-being: the social prestige of the teaching profession [9], the respect of all subjects of educational space, social security, freedom of choice, and the possibility of implementing professional and social expectations and claims $[10,11]$.

\subsection{Novelty and Significance}

The novelty and significance of the study are due to the presence of such methodological and methodical problems as the insufficient development of concepts and theories in Russian psychology and sociology that describe the construct of the teacher's professional well-being, as well as the lack of the problem statement of the dependence of the professional well-being level of the teacher on demographic indicators and the content of their direct activities.

\section{Literature Review}

A small number of scientific studies are devoted to the problems of teachers' professional well-being, despite the importance and priority of this problem, since an individual's psychological well-being, certainly, has positive impact on the quality and efficiency of a person's professional activities [11, 12].

There are several approaches to defining the content of the professional well-being notion. In each of these definitions, there is an implicit category of "relationships" [12], while the phenomenon of professional well-being is defined through an individual's psychological and social well-being, integratively manifested as a process and state, fixing the nature and content of human life activity in the profession, the conditions of its implementation, the main results of professional activities and an individual's attitude toward their results. On the whole, professional well-being is defined as part of psychological well-being, reflecting a positive assessment of oneself and one's own results in the profession [13].

The problem of measuring professional well-being is one of the key problems in Western psychology and sociology. British researchers [14], measuring the dynamics of the level of professional well-being in Britain based on the scales of "enthusiasm" and "satisfaction" by Warr [15], identify the key determinants of negative impact on an individual's professional well-being. Among them are the staff reduction, reorganization of working processes and institutions, reducing the choice of an individual's activities on the basis of a strong connection between the level of remuneration and the institution efficiency (rating); indicators of difficulties associated with employment; accelerating the pace of employment change, increasing job instability, and increasing adaptation efforts to constant changes in the professional (corporate) space.

In scientific studies of branches of sociology, psychology, economy, and management, various factors, positively influencing the growth of a person's professional well-being, are defined. Among them, the special, so-called "general" place is occupied by active participation or "co-participation" of a worker in the organization's professional life [16]. Thus, researchers consider two types of "co-participation" - participation in decision-making (at different levels) and financial participation in results (individually, in team, etc.). The process of participation in decision-making, which is a factor in the professional well-being growth [17], can be solved by the method of task allocation, which, on the one hand, forms an employee's commitment to the organization's values [18], and on the other hand, develops trusting relationships in the team [19]. The next factor in an individual's professional well-being growth is creating a situation of choice - the choice of the task, team, chief, methods for solving the problem [16, 20], etc. The methods of task allocation, freedom of choice and participation are only some elements in the "high involvement management (HIM)" model, which has undoubted impact on the effectiveness of an organization's activities [21].

However, the management of staff involvement, the creation of the illusion of choice, the influence on the process and the result of the organization's activities lead to the creation of abnormal, aggressive spaces, when a person does not experience freedom from space, which negatively affects a person's professional well-being [22]. In aggressive space, time dominates in relation to the will and intellect, when the tempo-rhythmic organization becomes a regulator of human activity. The problem of freedom in space and from space is obvious here [23].

Professional well-being is a multifactorial characteristic of an individual's state, which affects not only the efficiency of professional activities, but also the quality of life in general, and is determined on the basis of cultural, social, psychological, physical, economic, and spiritual factors. Thus, it seems insufficient to be guided by management studies in assessing the factors that influence professional well-being, and in assessing professional well-being itself, it is necessary to rely on the multiplicity of factors characterizing an individual's qualitative state, which is steadily manifested in a long period of time.

As a basis for identifying the criteria for professional well-being, the authors take a structural-level model of professional well-being including a system of descriptors: professional growth, professional self-acceptance, positive 
relationships with colleagues and autonomy in professional activities (methodology of psychological well-being by Ryff [24] in the adaptation of Zhukovskaya and Troshikhina [25] in relation to professional activities).

\section{Proposed Methodology}

\subsection{Methods}

To measure teachers' professional well-being, the modified methodology to assess psychological well-being by Ryff [24] in the adaptation of Zhukovskaya and Troshikhina [25] and symmetrical modification of Ruth, the methods for factorization, psychometric measurement, mathematical and statistical data processing were applied. For quantitative data, the calculation of descriptive statistics was performed: mean value, median, minimum and maximum values.

The results of testing the reliability and validity of the modified methodology for assessing the psychological well-being by K. Ryff in adaptation by L.V. Zhukovskaya, E.G. Troshikhina and in the symmetric modification by E.I. Ruth are presented in $[25,26]$

The methodology used in the research of a teacher's professional well-being consists of 54 statements, each of which was evaluated by the survey participants on a five-point scale from 1 to 5 . The statements were presented to the respondents in random order, but distributed in the analysis of the results into six groups corresponding to six components of teachers' professional well-being: autonomy in professional activities; competence as the possession of the environment in professional activities; personal and professional growth; positive relationships in the teaching staff; self-acceptance of oneself as a professional; life and professional goals.

The respondents, participating in the study of a teacher's professional well-being, filled out a survey form on the Internet in conditions convenient for them. To conduct the study, the period of the beginning of the school year was chosen to prevent the effects of fatigue-related factors that objectively appear in teachers by the school year end.
An experimental study of the dependence of teachers' professional well-being on such criteria as teachers' age, the type of financing of the educational organization, in which they are employed, and the content of teachers' activities was conducted.

\subsection{Purpose}

The purpose of the study is to identify by the above-mentioned criteria the features of conditionality of teachers' professional well-being components: autonomy in professional activities; competence as the possession of the environment in professional activities; personal and professional growth; positive relationships in the teaching staff; self-acceptance of oneself as a professional; life and professional goals.

\subsection{Participants and Venue}

The study was conducted in Nizhny Novgorod. The participants in the survey were 192 teachers aged 21 to 69 years old of different types of secondary educational organizations in Nizhny Novgorod. The women accounted for $92 \%$ of the respondents.

The age structure of the respondents in surveying teachers' professional well-being was characterized by heterogeneity: the younger age group (up to 35 years old) was $41 \%$; the average age group (from 36 to 55 years old) $-45 \%$, and the older age group (over 55 years old) was $14 \%$ of the total number of the respondents. The age structure of the body of the respondents in this study generally corresponded to the characteristics of the age structure of the regional teaching community [27]; there was a discrepancy in the lower proportion of representatives in the older age group of the respondents' total number.

The characteristics of the body of the respondents in the conducted study by the teaching experience, presented in Figure 1, confirms a fairly homogeneous composition with some prevalence of the proportion of teachers with experience up to 5 years $(24 \%$ of the total number of the respondents). 


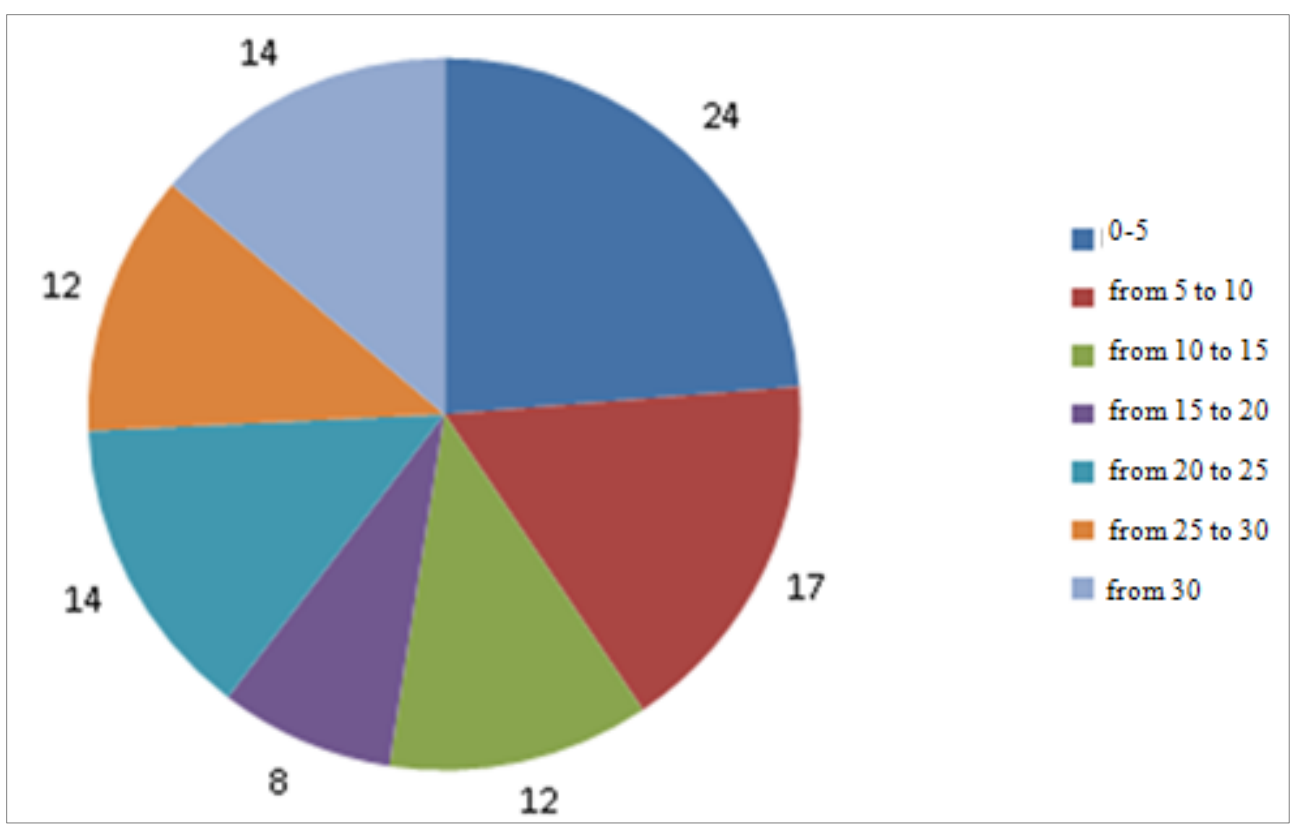

Figure 1. The respondents' characteristics by the teaching experience (in \%)

Among the study participants, there were representatives of different types of educational organizations in terms of financial independence: $45 \%-$ employed in autonomous educational organizations, $51 \%$ - in the budgetary ones.

Data on teachers: age, type of organization, teaching experience, the content of professional activities - were collected in the application procedure.

\section{Result Analysis}

In assessing the results of the research of a teaching community's professional well-being, three levels were identified. A high level of teachers' professional well-being is characterized by an average score of 4.5 to 5 . The teachers were considered separately by each of the criteria, and as a whole in total by all six criteria. A high level of professional well-being ensures the sustainable development of a teacher, a teaching community and the success of an educational organization's activities and professional activities.

A high level of professional well-being defines strengths for the formation of a zone of development of a particular teacher, and within the framework of this research, for the design of environmental decisions on the development of staff assistance in the educational system; these environmental decisions are based on strengths of a teaching community as a whole.

The authors leave out of the scope of this research of a teaching community's professional well-being an average level of professional well-being (within the mean value of 3.6-4.4 points on a 5-point scale). This context seems appropriate to be interpreted for compiling personal profiles of teachers' professional well-being. An average level of professional well-being for a teaching community as a whole is a steadily favorable general background, indicating a sufficient level of professional well-being, requiring point adjustments by the individual components - criteria.

A low level of teachers' professional well-being (from 1 to 3.5 points) states the presence of such characteristics of a professional community as low quality of professional life, teachers' dissatisfaction with the professional sphere, resulting in the inefficiency of activities.

Professional well-being is described in the research according to six criteria [25]. The criterion "Autonomy" (in Figures "A") means a teacher's independence and self-sufficiency in professional activities, independence in professional actions, ability to resist social pressure and act according to personal attitudes, standards, regardless of colleagues and surrounding people's opinions. A teacher, who has high performance, evaluates himself/herself and his/her behavior on the basis of personal professional beliefs. Low indicators testify to the presence of conformism and exposure to social pressure during the work performance, colleagues' expectations and assessments, leadership with decision-making based on the other people's judgments.

The criterion "Competence" (in Figures "C") assumes a formed sense of the possession of the surrounding work environment, circumstances, and situation. At high rates by this indicator, it is considered that a person possesses skill and professional competence, can carry out various types of activities, is able to find such ways of behavior, interaction, and application of the knowledge, skills and abilities in almost any work situation, which realize his/her professional needs and values. Low indicators by this criterion indicate difficulties in managing professional daily life, affairs, inability to realize opportunities and 
change the surrounding work environment, lack of a sense of control over the circumstances of the work sphere of life.

The criterion "Professional growth" (in Figures "PG" or "Prof. growth") means the level of development of a sense of continuous growth and professional potential realization. High scores by this criterion indicate a desire to gain new experience, a focus on improvement and knowledge of oneself as a professional, on increasing personal efficiency in work. A teacher sees that he/she can evaluate his/her professional growth and professional improvement. Low scores by the criterion mean that a teacher does not feel his/her professional development in time, is in the stagnation state, is bored and disinterested in work; the ability and desire for professional growth, the acquisition of new knowledge, skills and abilities are at the low level.

The criterion "Positive relationships" (in Figures "PR" or "Relationships") characterizes the quality of relations between colleagues in the teaching staff. A high score by this scale indicates a warm, trusting and constructive relationship between colleagues, bringing satisfaction. At low rates, a teacher lacks relationships with others, it is difficult for him/her to build trust; there is isolation in interpersonal relations.

The criterion of professional "Self-acceptance" (in Figures "S") characterizes self-acceptance of oneself as a professional, a teacher's attitude toward the level of his/her professionalism, towards personal characteristics manifested during professional activities. At high rates by this criterion, a teacher treats his/her professional and educational path in the present and past positively, realizes and accepts his/her professional achievements. Low rates indicate dissatisfaction with oneself as a professional, the presence of intrapersonal conflicts caused by anxiety due to lack of significant professional achievements, and disappointment with the past.

The criterion "Professional goals" (in Figures "PG" or "Prof. goals") means that professional activities are performed by a teacher with personal meaning on the basis of beliefs that have professional goals at high rates by the criterion. A teacher has a reason and purpose to work. Low indicators by the criterion testify to the lack of sense of meaning and direction in work, the absence of goals, ideas, and beliefs, which are internal motives to perform professional duties and cause interest and motivation for professional activities.

The research results allowed forming a general profile of teachers' professional well-being presented in Figure 2. A high level of professional well-being is indicated in green and forms according to the criteria: "Autonomy" 5\%; "Self-acceptance" - 9\%; "Professional goals" - 12\%; "Competence" - 14\%; "Positive relationships" - 15\% and "Professional growth" $-27 \%$ of the total number of teachers.

The proportion of teachers demonstrating professional well-being at the high level differs significantly by the criteria. Least of all teachers have such qualities as self-sufficiency and independence in professional activities. Most teachers who are not able to resist social pressure, are dependent on the opinions of colleagues and other participants of educational relations. A teacher's self-acceptance as a professional, a teacher's attitude towards the level of his/her professionalism, and towards his/her personal characteristics, manifested during professional activities, are directly connected with this criterion. Teachers' ability to resist social pressure and act according to their own attitudes and standards, regardless of other people's opinions is developed to the least extent. 


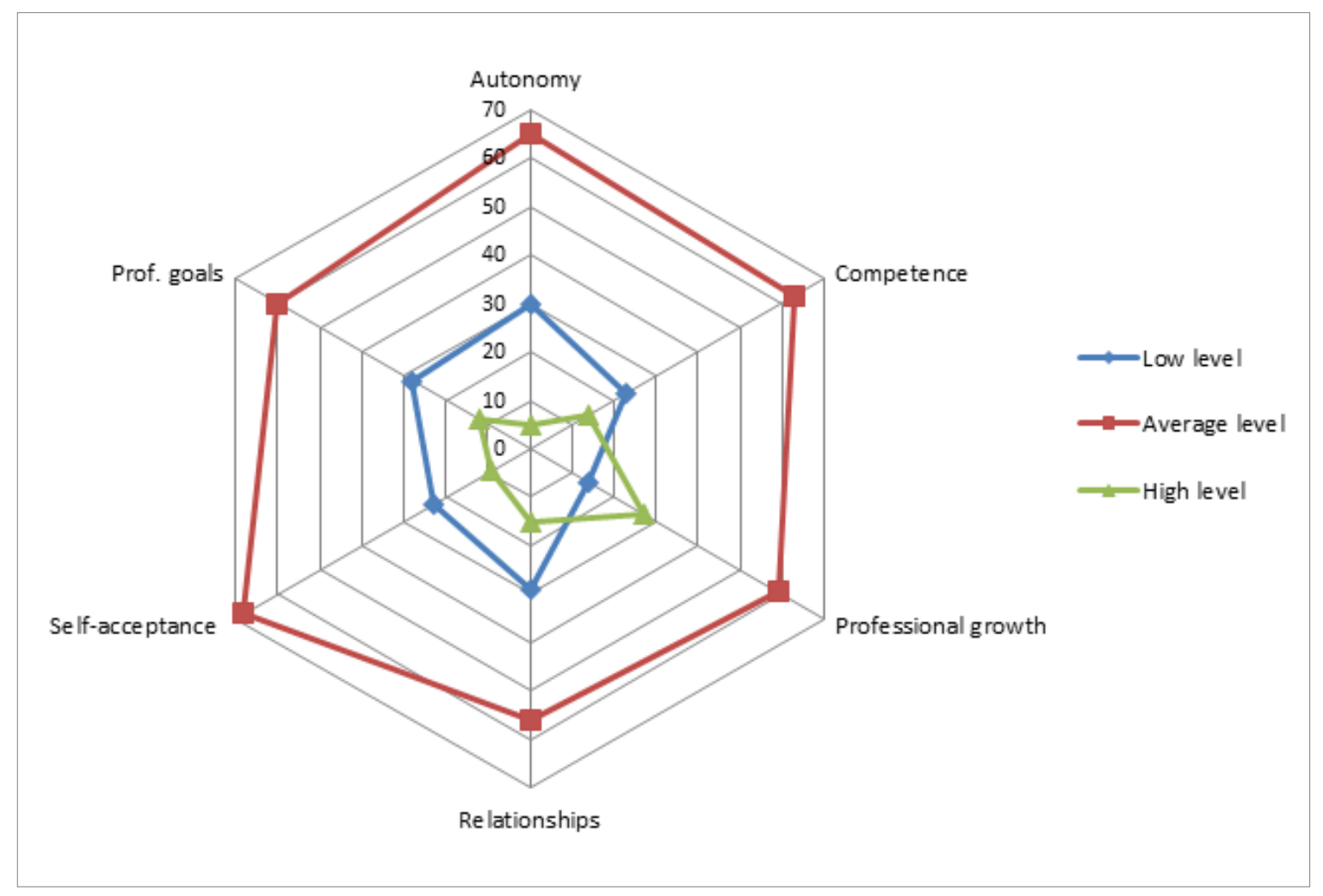

Figure 2. Profile of teachers' professional well-being compared to the average indicators by the criteria

The problem of a teacher's freedom is particularly significant in considering the educational process in the context of the transmission of educational services, which deliberately puts a teacher into a position of subordination in educational relationships. The thesis of a teacher's "subordinate" status merges with the Russian national ideal of a teacher, which is based on the phenomenon of duty, "sacrifice" - this causes the obligation of a teacher's "dependent" behavior in spite of his/her own personality, to the detriment of himself/herself. This feature has extremely negative impact on the social prestige of the profession, determining the pressure on a teacher from each subject of educational relations.

The strong point, on the basis of which it is necessary and possible to build activities to improve the level of teachers' professional well-being by all indicators, was a desire, expressed in $27 \%$ of the respondents, to gain new experience, focus on improving and knowing oneself as a professional, on increasing personal efficiency in work. This focus on self-development has always been a distinctive feature of a Russian teacher. At the same time, the indicator of the average level of teachers' professional well-being exceeding $50 \%$ speaks about the general favorable background in a teaching community.

A low level of professional well-being is indicated in blue in Figures 2 and 3 and forms according to the criteria: "Autonomy" - 30\%; "Competence" - 23\%; "Professional growth" - 14\%; "Positive relationships" - 29\%; "Self-acceptance" - 23\% and "Professional goals" - 28\% of the total number of teachers. Thus, at rough consideration one may state that about a quarter of teachers characterize their conditions as professional ill-being.

The total number of teachers demonstrating a low level of professional well-being exceeds the number of professionally successful teachers by five criteria except for the criterion "Professional growth" (Figures 2 and 3).

The comparative analysis of the level of professional well-being of teachers in budgetary and autonomous educational organizations has revealed some discrepancies, which, the authors suppose, can be attributed to the conditions that are created by different types of schools. 


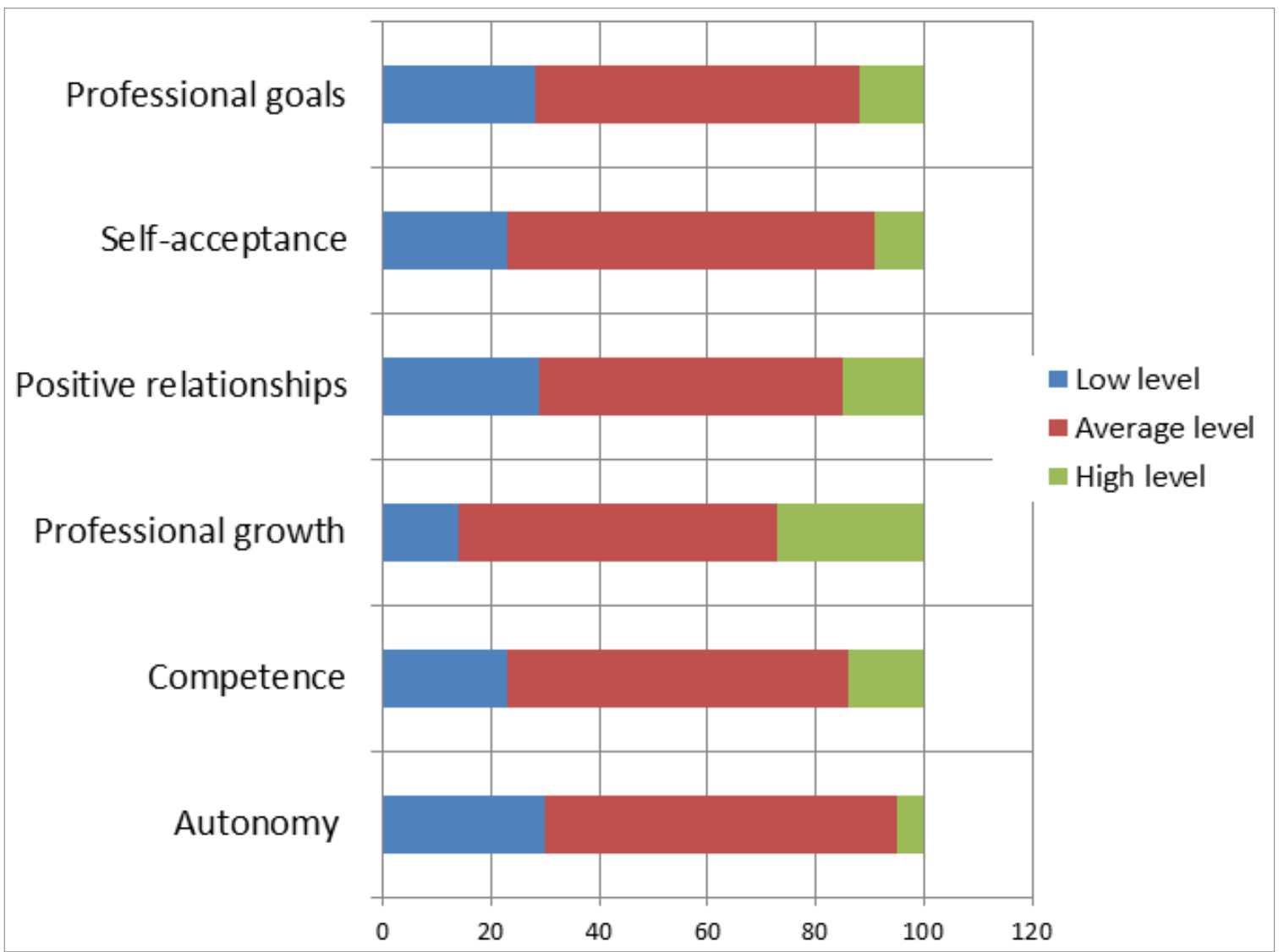

Figure 3. Profile of teachers' professional well-being compared to the average indicators by the criteria

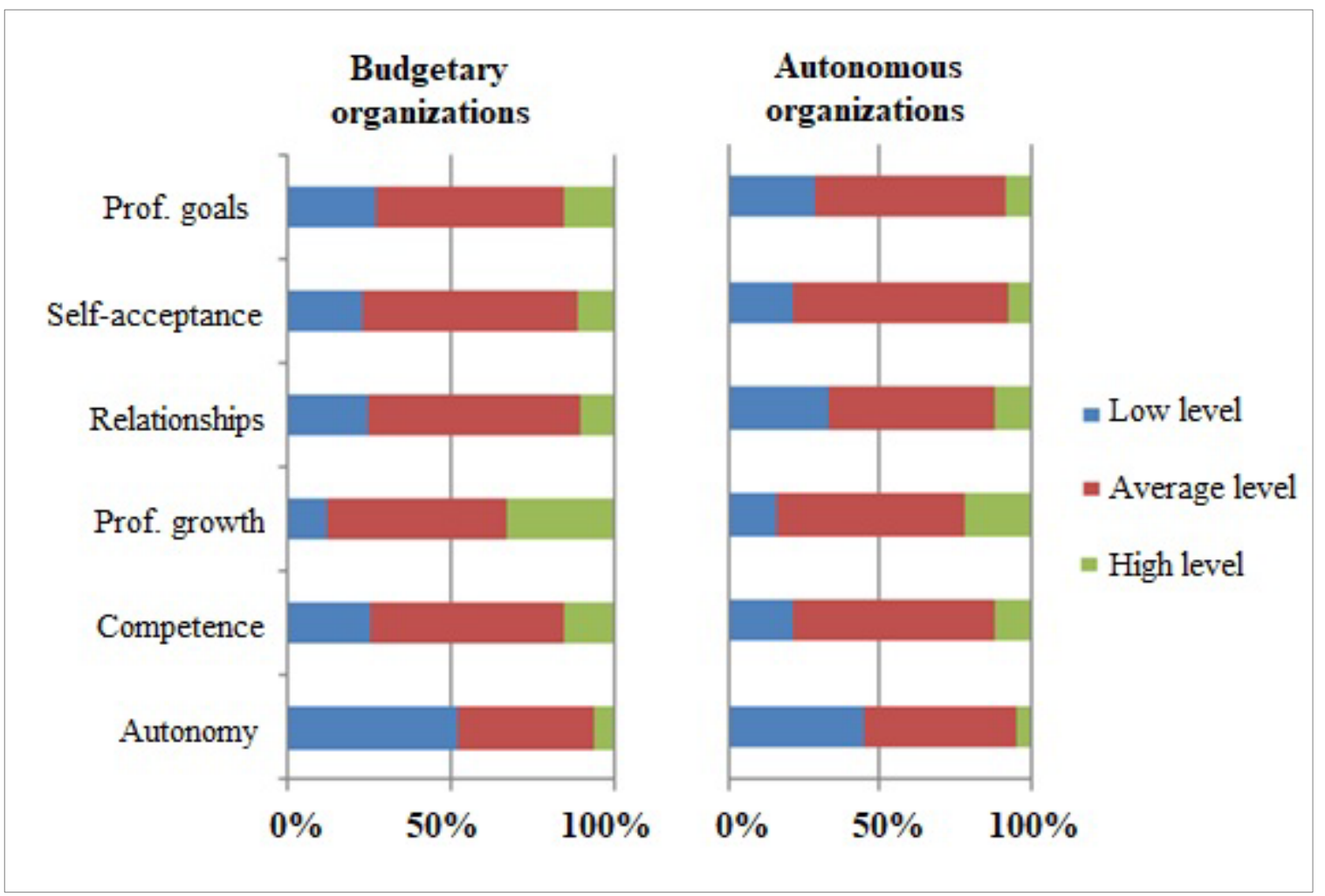

Figure 4. Comparison of average indicators of the professional well-being of teachers in budgetary and autonomous educational organizations 
First, the share of professionally successful teachers (Figure 4) is higher in budgetary educational organizations, while the share of teachers, who showed a low level of professional well-being, also exceeds the indicators of teachers in autonomous educational organizations.

Secondly, with a general similar profile of a combination of high, average and low levels of teachers' professional well-being for different types of schools, there are higher indicators for teachers in budgetary educational organizations by the criteria "Professional growth" and "Professional goals". By the criterion "Autonomy", teachers' professional well-being of different types of schools is approximately at the same level (at the level of statistical error). By the criterion "Autonomy" in budgetary organizations, teachers demonstrated an excess of the number of teachers with a low level of professional well-being over the number of teachers with an average level. In autonomous educational organizations, these indicators are equal (Figure 5).

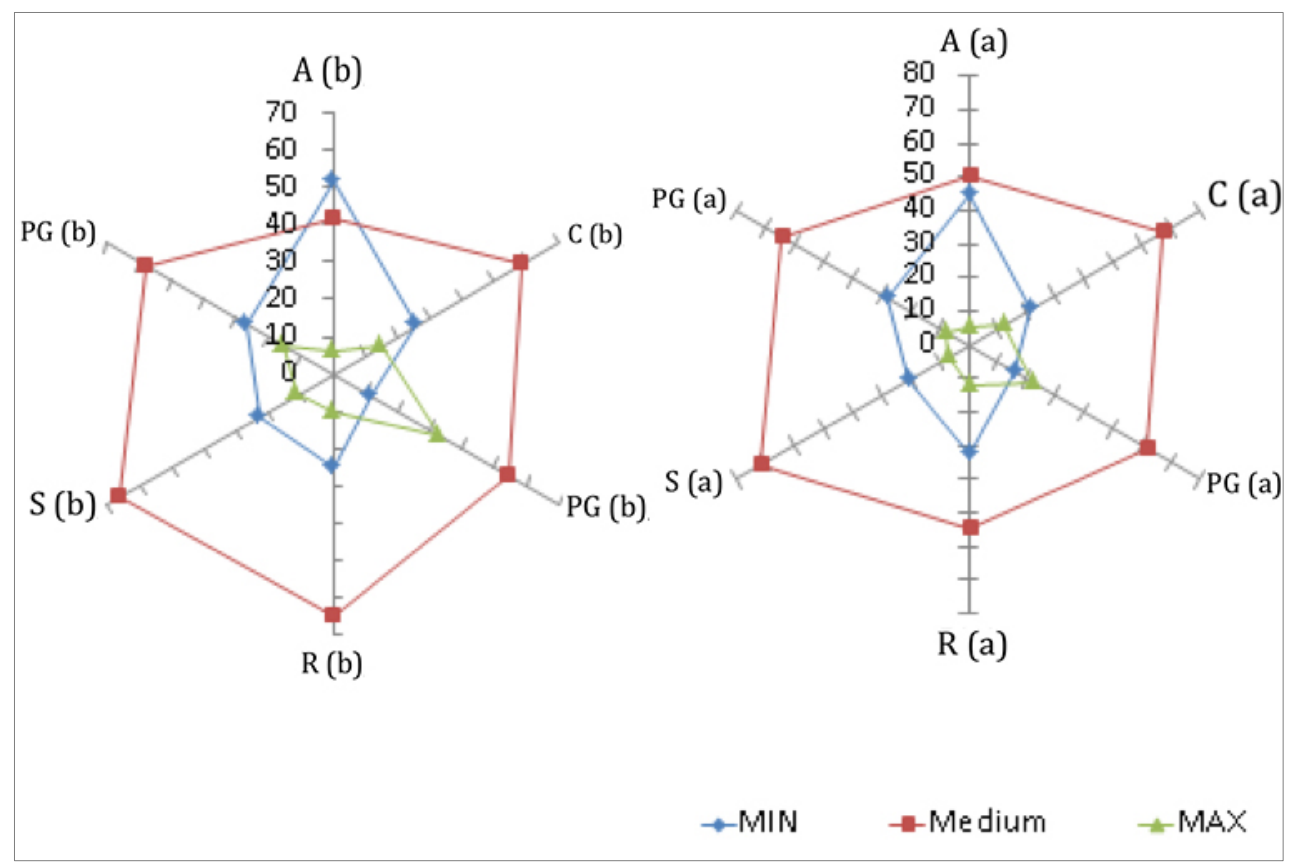

Figure 5. Comparison of indicators of the professional well-being of teachers in budgetary and autonomous educational organizations. Designation in the figure: (b) - budgetary educational organizations; (a) - autonomous educational organizations 


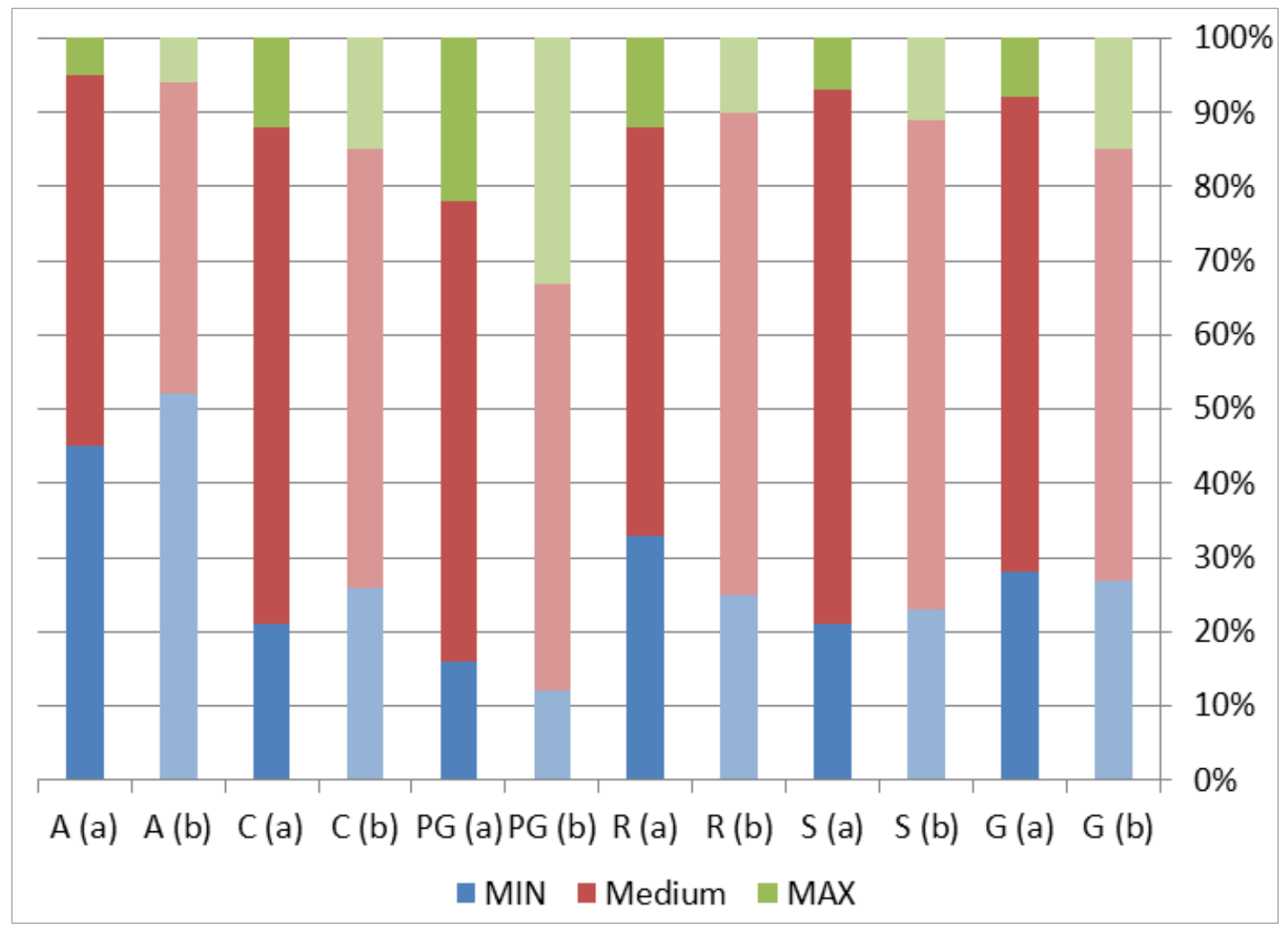

Figure 6. Comparison of indicators of the professional well-being of teachers in budgetary and autonomous educational organizations. Designation in the figure: (b) - budgetary educational organizations; (a) - autonomous educational organizations. Levels of professional well-being: min - low, medium - average; max - high

It seems (Figure 6 and 7) that budgetary organizations have created better conditions for teachers' professional growth; more teachers note positive relationships between colleagues in the teaching staff, and their professional activities are more marked by personal meanings and goals. 


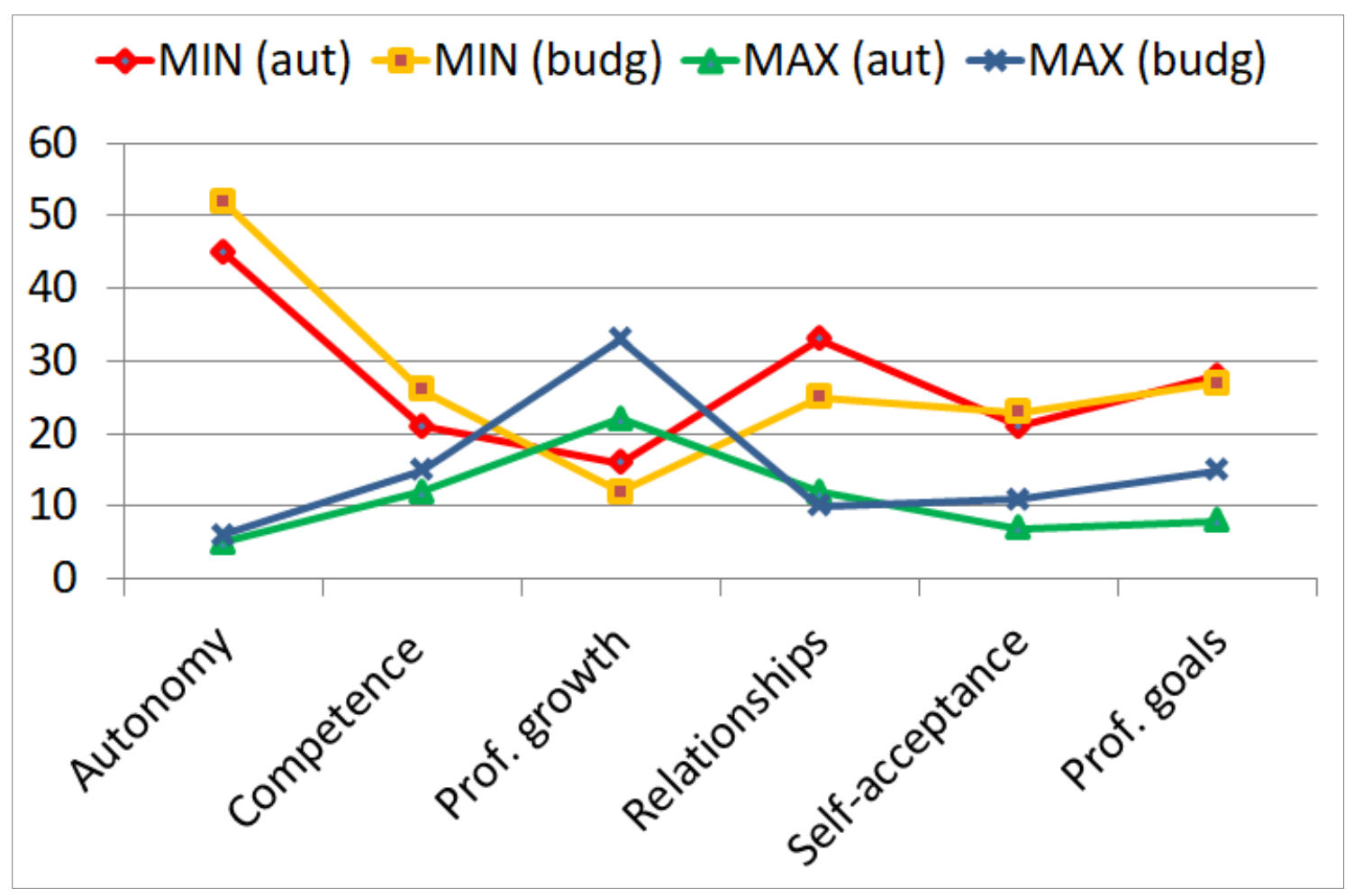

Figure 7. Comparison of the proportion (in the total number of teachers) of teachers with the minimum and maximum indicators of professional well-being. Designation in the figure: (budg) - budgetary educational organizations; (aut) - autonomous educational organizations. Levels of professional well-being: $\min$ - low, $\max$ - high

The comparative analysis by all six criteria of the average indicators of professional well-being of teachers, who perform administrative functions in addition to the pedagogical ones, and teachers, who have only pedagogical tasks, showed a higher level of professional well-being of teachers with administrative duties (Figure 8). The smallest discrepancy between these two groups of teachers was revealed by the indicator "Autonomy".

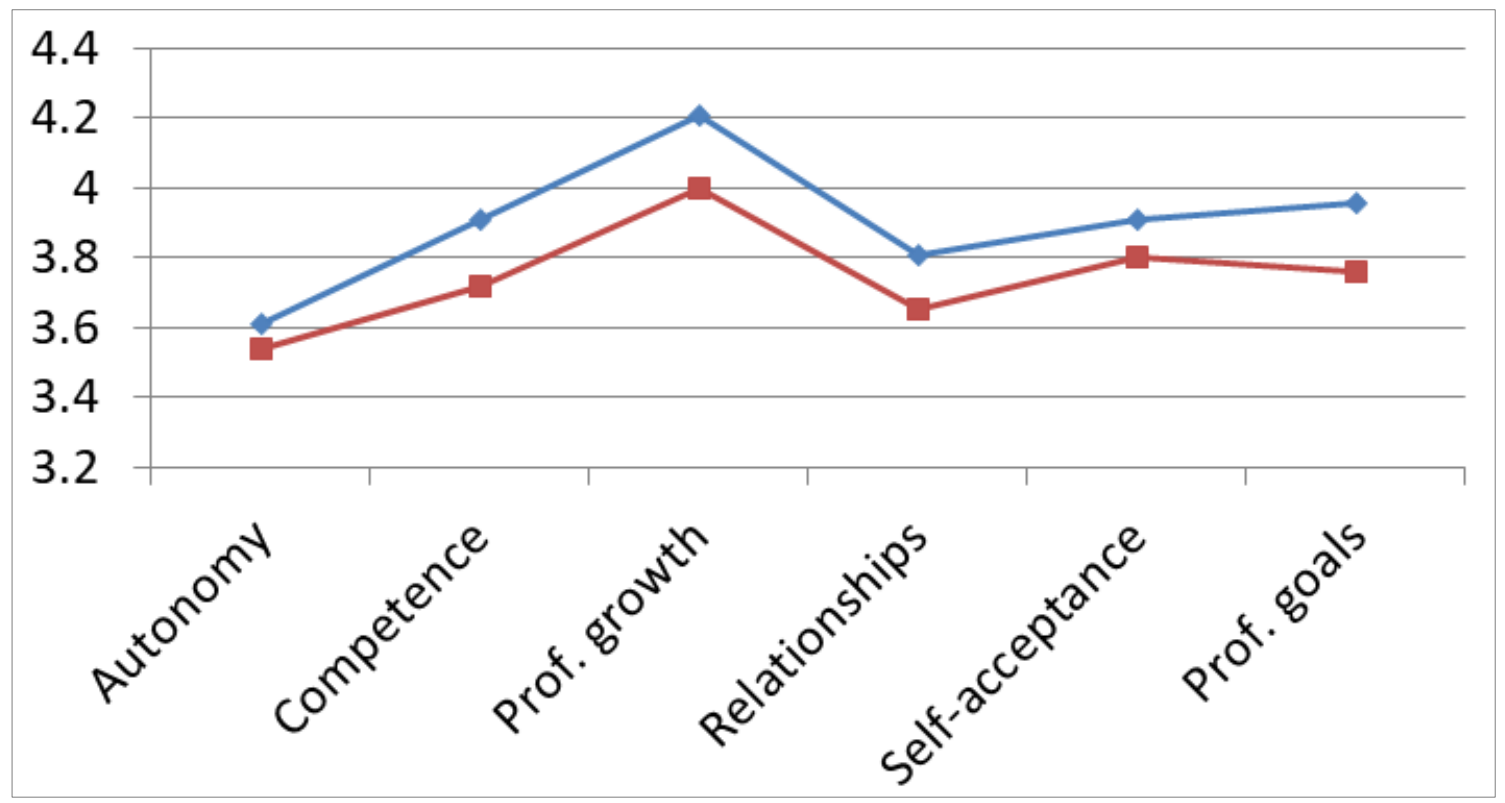

Figure 8. Teachers' professional well-being and content of activities. Designation in the figure: blue color - indicators of professional well-being of teachers performing administrative duties in addition to the pedagogical ones; red color - indicators of professional well-being of teachers performing only pedagogical duties. Average indicator of professional well-being on a 5-point scale 
The dynamics of changes in professional well-being were considered in three main age groups: the younger age group - teachers under the age of 35 years old; the middle age group - teachers aged 36 to 50 years old; the older age group - teachers over 50 years old. Figure 9 shows that the average indicators of professional well-being decrease with the increase in teachers' ages.
The analysis of the connection between the level of teachers' professional well-being and age (Figure 9) revealed an inverse dependence by most criteria except for the criteria "Autonomy" and "Self-acceptance". The indicators for these two above-mentioned criteria remain unchanged, persist the same within the statistical error for all three enlarged age groups of teachers.

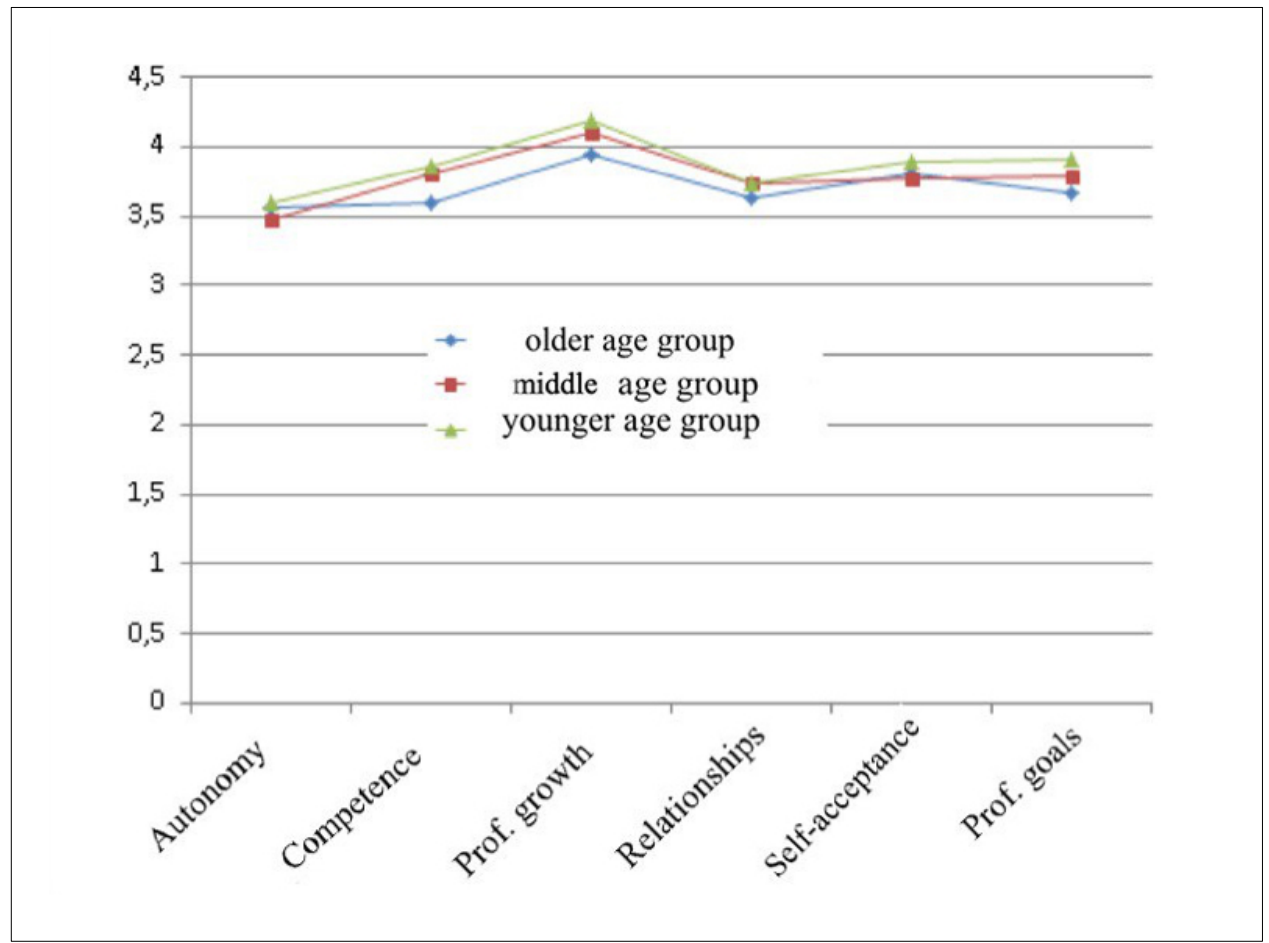

Figure 9. Dynamics of changes in the level of teachers' professional well-being and age

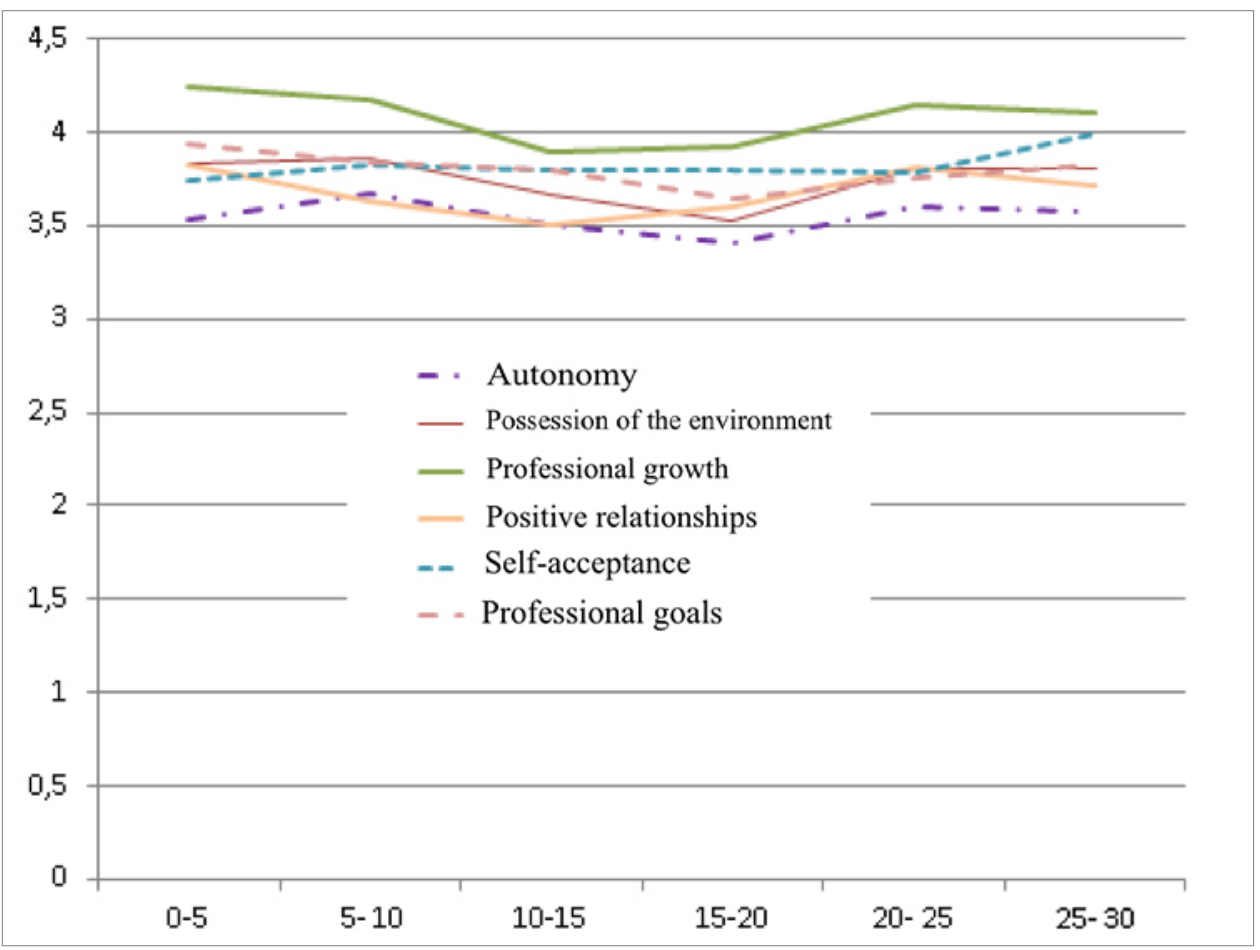

Figure 10. Teachers' professional well-being (average on a five-point scale) and experience (in years) 
The connection between teachers' experience and their professional well-being is expressed in a decrease in the level of professional well-being of teachers with experience from 10 to 20 years (Figure 10). Teachers with less (from 0 to 10 years) and more (from 20 years) experience have higher average indicators.

\section{Conclusions}

\subsection{Application}

The results of the study can be applied in the context of the problems of organizing effective support by the administration of educational institutions for the professional development of teachers, taking into account factors such as age, length of service, the content of professional activities of teachers and the type of organization that affect the professional well-being of teachers, systemic solutions for the development of human capital as the resource base of the organization, to support the teacher in overcoming the crises of professional activity.

\subsection{Limitations of the Study}

The limitations of this study are the lack of definition of the relationship of professional well-being with the problems of identifying specific professional crises and barriers in the professional activity of a teacher that directly affect the state of professional well-being.

The study analyzed pedagogical activity as the direct one, and administrative activity as the related one. However, the study does not consider other additional activities that can also have significant impact on the condition and level of professional well-being of a teacher.

The study does not examine the relationship between the level of professional well-being and other life factors such as, for example, the presence of family responsibilities for raising young children, support from family members in professional development, or, conversely, lack of family ties, etc.

\subsection{Suggestions for Further Research}

The research prospects are expanding the research context, taking into account various factors affecting the professional well-being of a teacher, including the nature of family relations, the presence of children, etc. Among the important aspects of further research are the identification and systematization of professional crises, the overcoming of which affects the level of teachers' professional well-being.

The perspective of this research is analyzing the discrepancy in the profiles of the dependence of teachers' professional well-being on their age and experience with identifying the correlation of experience and age in the modern Russian teaching community. In order to identify factors improving teachers' professional well-being, it is important to define activities, in addition to the administrative activity analyzed in this research, contributing to the growth of professional well-being.

One of the approaches to the search for differentiated environmental solutions for organizing work at the institutional and regional levels to improve professional well-being is to determine the factors affecting teachers' professional well-being at each stage of the life cycle of the teaching profession: entry into the profession, consolidation in the profession, maturity and exit from the profession, the study of the professional well-being dynamics in the transition to each following stage.

There is an obvious need to develop conditions for the growth of teachers' professional well-being, which creates a basis for improving the quality of education and its competitiveness, consolidation in the profession of young professionals. Retention in the profession is a significant factor in building a stable teaching community of an educational organization and a region. In accordance with the strengths of the teaching community, identified in the research of teachers' professional well-being, retention in the profession of novice teachers is provided by means of improving teachers' professional well-being.

The development of this research problem is the task of conducting a comparative study of teachers' professional well-being in different countries, identifying specific features and factors that determine the similarities and national differences.

\section{REFERENCES}

[1] E. Yu. Kostina. Sotsialnoe blagopoluchie i sotsialnaya bezopasnost $\mathrm{v}$ usloviyakh globalizatsii sovremennogo obshchestva [Social Well-Being and Social Security in the Globalization of Modern Society], Universum: Obshchestvennye nauki, Vol. 6, No. 16, 2015. Online available from http://7universum.com/pdf/social/6(16)/Kos tina.pdf.

[2] E. Yu. Ilaltdinova, V. V. Kisova. Pedagogicheskaya odarennost i pedagogicheskii intellekt: proektirovanie teoretiko-prikladnykh podkhodov [Pedagogical Giftedness and Pedagogical Intelligence: Designing Theoretical and Applied Approaches], Vestnik Mininskogo universiteta, Vol. 6, No. 4, 9, 2018.

[3] O. V. Suvorova, E. V. Minaeva, N. V. Ivanova, E. B. Mamonova, S. N. Sorokoumova. Communicative Behavior of Pedagogics Students in Relation to the Structure of the Parental Families, Revista Espacios, Vol. 40, No. 23, 2019. Online available from http://www.revistaespacios.com/a19 v40n23/19402301.html

[4] E. Kryukova, N. Bodneva, T. Sribnaya, N. Filimonova, O. 
Vershinina. The Development of the Restaurant Business in Russia, Journal of Environmental Management and Tourism, Vol. 10, No. 2, 2019. Online available from https://journals.aserspublishing.eu/jemt/article/view/3349

[5] M. G. Sergeeva, V. N., Skvortsov, I. V. Poliakova, O. V. Matveev, E. V. Luchina, Y. A. Mamaeva, A. A. Suchilina. Professional Self-Determination of Students in the Implementation of Competency-Based Learning in Vocational Education, Revista Espacios, Vol. 40, No. 26, 7, 2019. Online available from http://www.revistaespacios.co m/a19v40n26/19402607.html

[6] S. I. Aksenov, R. U. Arifulina, T. K. Belyaeva, D. A. Gusev, E. Yu. Ilaltdinova, I. V. Lebedeva. In the Search of National Ideal of Russian Pedagogue, Journal of Entrepreneurship Education, Vol. 20, No. 3, 5, 2017.

[7] E. Yu. Ilaltdinova, I. V. Lebedeva, S. V. Frolova. Top Qualities of Great Teachers: National and Universal, Advances in Intelligent Systems and Computing, 677, 2017.

[8] E. S. Medkova. Sculpture in Modern Environment: Educational Technology, International Journal of Innovative Technology and Exploring Engineering, Vol. 8, No. 10, 2019. Online available from https://www.ijitee.org /wp-content/uploads/papers/v8i10/J94520881019.pdf

[9] A. A. Fedorov, G. A. Paputkova, E. Yu. Ilaltdinova, I. F. Filchenkova, S. V. Frolova, O. V. Bogorodskaya, E. N. Perevoshikova. Portret pedagoga. Osnova modelirovaniya obrazovatelnykh programm [A Teacher's Portrait. The Basis of Modeling Educational Programs]. Minin University, Nizhny Novgorod, 2017.

[10] S. Zhienbayeva, A. Kalysh, A. Zhubandykova, R. Nabuova, A. Issayeva, O. Abilmazhinova, A. Ahmuldinova. The Model of Professional Competence Development in Future Physical Education Teachers at an Entrepreneurial University, Revista Espacios, Vol. 40, No. 31, 7, 2019. Online available from http://www.revistaespacios.com/a19 v40n31/19403107.html

[11] O. R. Shefer, S. V. Kraineva, I. I. Bespal. Visualization of the Formation of Undergraduate Competencies, Revista Espacios, Vol. 40, No. 29, 29, 2019. Online available from http://www.revistaespacios.com/a19v40n29/19402929.htm

[12] I. V. Zausenko. Lichnostnye determinanty psikhologicheskogo blagopoluchiya pedagoga. Avtoref. dis.... kand. psikh. nauk [Personal Determinants of a Teacher's Psychological Well-Being (Ph.D. Thesis Abstract)]. Ekaterinburg. (p. 24), 2012.

[13] G. L. Puchkova. Subektivnoe blagopoluchie kak faktor samoaktualizatsii lichnosti. Avtoref. kand. psikh nauk [Subjective Well-Being as a Factor of Personality Self-Actualization (Ph.D. Thesis Abstract)], Khabarovsk, 2003.

[14] F. Green, A. Felstead, D. Gallie, H. Inanc. Job-Related Well-Being through the Great Recession, Journal of Happiness Studies, Vol. 17, No. 1, 389-411, 2016.

[15] P. Warr. How to Think About and Measure Psychological Well-being. In M. Wang, R.R. Sinclair, \& L.E. Tetrick (Eds.), Research Methods in Occupational Health Psychology: Measurement, Design and Data Analysis (pp. 76-90), Psychology Press/Routledge, New York, 2013.
[16] P. Böckerman, A. Bryson, P. Ilmakunnas. Does High Involvement Management Improve Worker Wellbeing? Journal of Economic Behavior \& Organization, Vol. 84, 660-680, 2012.

[17] E. Cottini, C. Lucifora. Mental Health and Working Conditions in Europe, Industrial and Labor Relations Review, Vol. 66, No. 4, 958-988, 2013.

[18] F. Green. Leeway for the Loyal: A Model of Employee Discretion, British Journal of Industrial Relations, Vol. 46, No. 1, 1-32, 2008.

[19] A. Fox. The Meaning of Work. In G. Esland, \& G. Salaman (Eds.), The Politics of Work and Occupation (pp. 131-191), University of Toronto Press, Toronto, 1980.

[20] D. Gallie, Y. Zhou, A. Felstead, F. Green. Teamwork, Skill Development, and Employee Welfare, British Journal of Industrial Relations, Vol. 50, No. 1, 23-46, 2012

[21] S. Wood, L. M. de Menezes. High Involvement Management, High Performance Work Systems and Well-Being, The International Journal of Human Resource Management, Vol. 22, 1586-1610, 2011.

[22] I. G. Dolinina, O. I. Korchagina. Forming the Civic Participation and Culture Interethnic Interaction of Students, International Journal of Recent Technology and Engineering, Vol. 8, No. 3, 2019. Online available from https://www.ijrte.org/wp-content/uploads/papers/v8i3/C59 41098319.pdf.

[23] S. V. Frolova, E. Yu. Ilaltdinova, F. V. Povshednaya. Proektirovanie vospitatelnogo prostranstva obrazovatelnoi organizatsii: Monografiya [Design of Educational Space in Educational Organizations: Monograph], Flinta, Moscow, 2017.

[24] C. Ryff. The Structure of Psychological Well-Being Revisited, Journal of Personality and Social Psychology, Vol. 4, No. 69, 719-727, 1995.

[25] L. V. Zhukovskaya E. G. Troshikhina. K. Ryff's Scale of Psychological Well-being, Psychological Journal, Vol. 1, 82-93, 2011.

[26] E. I. Ruth (Tueva), L. I. Augustova. Professional well-being of employees of commercial organizations: criteria and assessment method, Scientific research of graduates of the Faculty of Psychology, St. Petersburg State University, Vol. $5,72-78,2017$

[27] A. A. Fedorov, M. Yu. Soloviev, E. Yu. Ilaltdinova, G. V. Kondratyev, S. V. Frolova. Vozrastnaya struktura pedagogicheskogo soobshchestva: analiz i prognoz razvitiya: analiticheskii doklad [Age Structure of a Teaching Community: Analysis and Forecast of Development: Analytical Report], Minin University, Nizhny Novgorod, 2018. 